\title{
The Research of Higher Vocational School Mechanical Engineering Training Center Building Model by School-enterprise Cooperation

\author{
Qingyun Meng
}

Department of mechanical engineering, Dalian vocational \& technical college , Dalian ,Liaoning, China

Email:874702490@qq.com

\begin{abstract}
Keywords: higher vocational school mechanical engineering, training center, school-enterprise cooperation
\end{abstract}

\begin{abstract}
School-enterprise cooperation building training center is the only road for the development of higher vocational school training. Because of the particularity of mechanical training teaching, there are some problems in equipment maintenance, consumables management, teaching operation. Raise higher demands on the school-enterprise cooperation model, according to it, we should combine with practice and searching more reasonable, perfect mechanical engineering training center building model by school-enterprise cooperation.
\end{abstract}

\section{Introduction}

In the decision on Accelerating the development of modern vocational education (No.19 Document of State Council, 2014) "Accelerate the establishment of modern vocational education system" pointed out that "Sound the system of enterprises to participate in. Formulate relevant laws and incentive policies to promote school-enterprise cooperation, deepen the integration of production and education, encourage the industry and enterprises organize or participate in vocational education, give play to the role of enterprise important governance subject". It requires higher vocational colleges in a timely manner to understand dynamic enterprise demand, make full use of enterprise resources, and expand the depth and breadth of university-enterprise cooperation. Mechanical engineering has the particularity of its practice teaching. There are some problems in equipment maintenance, consumables management, teaching operation. How to effectively supported by enterprise and cooperate in building higher vocational colleges training center. It is the major problem in mechanical professional training education development in higher vocational colleges facing major problems. Explore higher vocational school mechanical engineering training center building model by school-enterprise cooperation is the main problem to be solved.

\section{The Main Problems in Higher Vocational School Mechanical Engineering Training Center}

Higher vocational colleges as services in the development of local, the cultivation of graduates should have a higher level of professional skill, practical ability and innovative spirit, and can achieve seamless docking with the production of the enterprise needs. The above ability mainly relies on the practice teaching of the campus, so practical teaching occupies an important position in the process of talent cultivation in higher vocational colleges. Training center teaches skill training and improves students in campus. The traditional education method only relied on college has been difficult to cultivate talents to adapt to the modern enterprise development. Now much machinery of practical training center problems embodied as follows.

The Existing Training Equipment is Inadequate or Outdated. Vocational education training center construction needs more money than ordinary higher education training center. But due to the limitation factors such as location, funds, many schools instruments and equipment performance, specification and quantity can't meet the ministry of education promulgated standard, and some even behind the practical technology of production enterprises, which can't reach the efficient demonstration training function. Engineering training center is shortage of working stations and tends to adopt group training. Student practical time is less than the time needed for the teaching 
arrangement. That can't fully meet the requirements of practice teaching.

Training Center Management Operation Mode is in Teaching Model. Influenced by traditional teaching mode, management of practice training center mainly tends to teaching management. It is not the real realization enterprise management operation mode, which leads to the direct problem that $6 \mathrm{~s}$ management implementation does not reach the designated position, material and equipment are lack of a system to monitor; Equipment maintenance is system specification, and equipment being used but no one manage it. Training center is lack of ability of sustainable development.

Practice Teaching Team Skills Level is not High. “Two-qualification” teachers have strong practical operation skills who is the construction of practice base and the dominant force in teaching operating skills, but "two-qualification" teachers in higher vocational colleges is not enough, and even some are more in name than in reality. Their skills need to be improved, and master advanced technology update slower, often dominated by traditional project teaching. It is difficult to give students advanced skills training. This seriously restricts the further development of practice teaching.

Those problems in the development of vocational education gradually make further development of higher vocational practice teaching slowly. To fundamentally reverse the current situation, it needs to attract in the leading technology development enterprises, realize the school-enterprise cooperation building training center, put management and teaching together. Guided by the needs of the enterprises, improve training center of production function, the teaching function, service function, and the ability of sustainable development, and effective improve the quality and scale of practice teaching of vocational colleges.

The Meaning of Higher Vocational School Mechanical Engineering Training Center Building Model by School-enterprise Cooperation

Solve the Shortage of School Training Center Teaching Resources. Students' practice teaching requires a lot of training instrument, equipment and faculty. Training center's hardware should not only have a certain number and the size of the conventional equipment, but also must have a certain number, many layers, meet the requirement of enterprise production of advanced processing equipment, which provides students an environment similar with the actual production.

With enrollment expansion of universities in our country, compared with the theoretical teaching, practice teaching's shortage of resources is more outstanding. It is difficult to solve this problem only by universities. The problems such as equipment maintenance and consumables management in mechanical engineering training center is growing, which badly in need of enterprise management. Introduce enterprise resource not only makes the students share the enterprise of modern engineering technology and the advanced project management idea, but also can effectively alleviate the shortage of school resources and the rigid training center management problem. At the same time this kind of cooperation saves the cost of human resources training for the enterprise.

Enterprising Training Center Teaching Process is Helpful to Cultivate the Students' vocational Skills and Professional Quality. Students in the basic real enterprise environment complete the actual production and tasks, and even some students can participate in the scientific research project that led by teachers and enterprise. It achieves the combination of theory teaching and production practice. The students' vocational skills training have the effect of getting twice the result with half the effort. At the same time, this process is to make the students influenced by osmosis, and it cultivates students with engineering language to ask questions, the ability to analyze and solve problems. Students adapt to the enterprise production environment in advance, and conducive to the cultivation of the students' professional ethics and professional quality.

Broaden the Students' employment Channels, Reserve Talents for the Enterprise. School-enterprise cooperation construction mechanical training center pay attention to students in actual engineering production environment, and let the talent cultivation in colleges and enterprises cross into two different environments to promote each other. Students were involved in the company's production and technical work during the process of practice teaching, which trained students' professional skills, good professional quality and team cooperation ability. This kind of 
training mode also can make students understand the technical and cultural needs of enterprises in advance. It makes the students feel the atmosphere of the enterprise, accelerate the talent cultivation, adapt to the working life as soon as possible after graduation to enter production environment for them. In addition, after graduation, the cooperative enterprise can choose priority performance excellent talents, which broadens the employment channels, but the school also supplies the excellent talents for the enterprise.

Help the Reform of Practice Teaching in Schools. School-enterprise cooperation in construction mechanical training center can overcome the disadvantages of "work behind closed doors" in higher vocational colleges. It makes school have conditions to adjust specialties and talent training plan according to the enterprise. It combines the production practice of course system and teaching content updates, also reforms and improves teaching methods and means. Under the support of cooperative enterprises, the teaching reform can solve the problems of the school education far from social demands, which makes the school training of talents can meet the demand of social production.

\section{New Higher Vocational School Mechanical Engineering Training Center Building Model by School-enterprise Cooperation}

Starting from the actual, exploring vocational mechanical engineering training center building model between colleges and enterprises should set out to the following three aspects: Establishing and improving the training center management system is the guarantee of the school-enterprise cooperation training center ; Building the actual engineering environment is a necessary condition for the enterprise needs talent cultivation; Optimizing the practice teaching course structure, renewing the content of the practice teaching is the quality guarantee of talent training.

Establish and Improve the School-enterprise Cooperation Mechanical Training Center Management System. School-enterprise cooperation in construction machinery training center is a kind of new education training mode. It is a school together with the enterprise to participate in the construction of training center of education training mode. It involves the different interests, so before the cooperation must clear their respective responsibilities and obligations, personnel appointment and management, the principle of distribution of interests and methods. It provides the necessary guarantee in school-enterprise cooperation building training center.

Clear the Subject Status of the School. In the process of school-enterprise cooperation training center, schools and enterprises may have different idea in teaching arrangement, resource allocation, which requires the school grasp decision-making and the development direction of training center, combine with the national policy, define the direction of the education teaching reform, put practice teaching in the first place. It can't just pursuit of school-enterprise cooperation, and do not care the practice teaching quality.

Safeguard the Legitimate Interests of Enterprises. The purpose of school-enterprise cooperation construction training center is to achieve a win-win result. This requires maximum arouse the enthusiasm of the participation of enterprises, and solve the enterprises concerning problems. In addition to deliver high quality talents for the enterprise, but also become the reserve force of the enterprise, providing technical support and equipment support for enterprise technical research and production distribution. Also can be common in technical renovation, declare production, project, etc.

Updating the Management Mode of Practice Teaching, Building Engineering Practical Environment. Previous training center environment stays priority into teaching, and the production is complementary in this state. It has been unable to adapt to the needs of the development of higher vocational education, and it is hard to cultivate talents can meet the demand of society and the enterprise production. In view of this, should be based on the traditional training center, relied on the support of the enterprise, introduced the persons with higher production management experience to improve the training center management mode, such as: training center structure according to the form of enterprise organization structure; Training center management according to the specifications of the standard of the enterprises; Teaching projects bring business case, simulating 
different post responsibility and rights. Also should introduce high levels of skill and practice teaching teachers and advanced productivity training equipments.

Optimize the Curriculum Structure, Updating the Teaching Contents. School-enterprise cooperation construction training center close ties between the school, enterprise and society. It makes the school in accordance with the society and the enterprise needs to adjust specialties and talent training plan. Existing curriculum structure, teaching and form have gradually with the engineering practice, which can't meet the high skills, the cultivation of innovative ability. So it must change the traditional pattern of practical education, optimize course structure and renew the content of the practice teaching. It requires professional teachers with the enterprise control scheme of talent cultivation, optimizing course structure, designing production content and training target and docking, practicing teaching content and the form of the production process of organic blend in practice teaching. The teaching content and enterprise combined closely with the actual to effectively improve the teaching quality.

\section{Higher Vocational School Mechanical Engineering Training Center Building Model by School-enterprise Cooperation is the only Way to Realize the Win-win between Colleges}

School-enterprise cooperation training center is a kind of open education mode. It through the enterprise to participate in the school, putting the school in the field of education teaching superiority and the advanced nature of the enterprise in the field of production technology and production management in the field of standardization together. Combine the professional knowledge education and the production practice of training. Put the classroom knowledge in school and the acquisition of practical experience and skills in production site together through the cultivation of the students. It solve the problems that most higher vocational colleges in our country currently training center lacked the knowledge of advanced production technology and enterprise culture environment. It through the school-enterprise cooperation makes training center construction into a base of production-teaching-research combination, and have stronger education teaching and production capacity. It also becomes the best place to new product development, production enterprises and technology transfer. It is the only way to realize school-enterprise cooperation and win-win both sides

\section{Acknowledgement}

Researching results of 2016 subject "the research of higher vocational school mechanical engineering training center building model by school-enterprise cooperation" of the 13th Five-Year Plan of Liaoning province education science. (Project number: JG16EB066, topic moderator: Qingyun Meng)

\section{References}

[1] Wenbiao Jiang, Ye Chen, school-enterprise cooperation laboratory strengthening practice teaching application[J]. Laboratory research and exploration, 2011(11).

[2] Dexin Zhang, Jun Li, Aiping Li. School-enterprise cooperation professional management platform mode exploration and practice [J]. Shiyan journal of vocational and technical college 2011(4).

[3] Jian $\mathrm{Wu}$. Base on the training mode of cooperation between colleges train practical base construction [J]. Journal of vocational education BBS, 2011 (17).

[4]Zhiqi Cao, Qiuping Chen, Qiumei Huang. The exploration and practice of university-enterprise cooperation laboratory-Guangdong Lingnan institute of technology, for example [J]. Journal of Wuxi vocational and technical college, 2011 (3).

[5] Lingming Shi, Changde Fu. School-enterprise cooperation under the framework of productive 
practice in higher vocational colleges to study [J]. Journal of education and profession, 2008 (6)

[6] Liandong Sun, Xiaomin Li. Research of the construction of training base in higher vocational campus [J]. Journal of vocational education research, 2006 (7).

[7] Guxing Guo, Youan Qu. Higher vocational school training base construction practice [J]. Journal of vocational and technical education in China, 2006 (33).

[8] Guoquan $\mathrm{Xu}$. The concept and practice of the higher vocational education training base construction [J]. Journal of laboratory research and exploration, 2009 (3). 